\title{
LYMPHOCYTIC ABNORMALITIES IN A MOTHER SUGGESTING TRANSIENT ANTIPHOSPHOLIPID ANTIBODIES DURING A PREVIOUS UNSUCCESFUL PREGNANCY
}

\author{
Constantinos Tsompos \\ Obstetric and Gynecologic Wards, General Hospital, Messolonghi, Greece
}

\section{ABNORMALNOSTI LIMFOCITA KOD MAJKE UKAZUJU NA TRANZITORNA ANTIFOSFOLIPIDNA ANTITELA TOKOM PRETHODNE NEUSPEŠNE TRUDNOĆE}

\author{
Konstantinos Tsompos \\ Odeljenje ginekologije i akušerstva, Opšta bolnica, Mezolongi, Grčka
}

\begin{abstract}
Presence of antiphospholipid antibodies during a pregnancy represents a great challenge for the obstetrician. The appropriate medical measures usually result in significant improvement of the perinatal outcome. However, findings of routine diagnostics are sometimes normal and additional exercise is needed.

Woman, 36 years old, in her third pregnancy, was admitted due to missing fetal movements. Fetus, 40 weeks of gestational age, had absent sounds and vaginal labor was augmented. A stillborn male neonate had weight of $4000 \mathrm{~g}$, the umbilical cord was normal and it was not wrapped. However, after the pregnancy abnormalities of lymphocytic cell line were found. There was a lymphocytosis in which relative proportion of $B$ lymphocytes was increased (range $40 \%$ to $44.8 \%$ ), absolute number of T lymphocytes (CD3+) increased (range 1992/ $\mathrm{mm}^{3}$ to $2081 / \mathrm{mm}^{3}$ ) and relative proportion of $T$ lymphocytes (CD4+) increased in the range from $62 \%$ to $70.2 \%$. After three years the woman was in her fourth pregnancy which was meticulously followed-up. Only subtle lymphocytic changes appeared, pregnancy course and labor were normal and healthy male neonate, weight of 3520 $g$, was finally born.

Pattern of lymphocytic reaction between two consecutive pregnancies and during the last one with different clinical outcomes suggests development of transient antiphospholipid antibodies in the mother during her third pregnancy. It is likely that these antibodies triggered the chain of pathological events which finally contributed to the fetal demise.
\end{abstract}

Key words: pregnancy; antibody, antiphospholipid; stillbirth.

\section{INTRODUCTION}

Diagnosis of antiphospholipid syndrome includes the following criteria: a patient has the syndrome if he or she is experiencing at least one of the two clinical findings (either vascular thrombosis or obstetric complication) and one of the two laboratory findings (either positive lupus anticoagulant or $\beta 2$-glycoprotein I ( $\beta 2 \mathrm{GPI})$ IgG antibodies

\section{SAŽETAK}

Prisustvo antifosfolipidnih antitela tokom trudnoće predstavlja veliki izazov za akušera. Adekvatne medicinske mere obično rezultiraju značajnim poboljšanjem perinatalnog ishoda. Međutim, rezultati rutinske dijagnostike su ponekad normalni kada su potrebna dodatna ispitivanja.

Žena, 36 godina, u svojoj trećoj trudnoći, primljena je zbog odsustva fetalnih pokreta. Fetus, 40 nedelja gestacijske starosti, je imao odsutne tonove $i$ indukovan je vaginalni porođaj. Mrtvorođeno muško novoođenče je imalo težinu od $4000 \mathrm{~g}$, pupčanik je bio normalan i nije bio obavijen. Tok trudnoće je inače bio normalan. Međutim, nakon trudnoće pronađene su abnormalnosti limfocitne ćelijske linije. Bila je prisutna limfocitoza u kojoj je bio povećan relativni odnos $B$ limfocita (rang 40\% do 44,8\%), apsolutni broj T limfocita

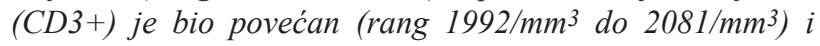
relativni odnos $T$ limfocita $(C D 4+)$ je bio povećan, $u$ rasponu od $62 \%$ do $70,2 \%$. Nakon tri godine žena je bila u svojoj četvrtoj trudnoći koja je pažljivo praćena. Pojavile su se samo suptilne promene limfocita, tok trudnoće i porodjaj su bili normalni i rodjeno je zdravo muško novorođenče, težine $3520 \mathrm{~g}$.

Obrazac limfocitne reakcije izmedju dve uzastopne trudnoće $i$ tokom poslednje, sa različitim kliničkim ishodima,ukazuje na prisustvo prolaznih antifosfolipidnih antitela kod majke tokom njene treće trudnoće. Vrlo je verovatno da su ova antitela pokrenula tok patoloških događaja koji su konačno doprineli smrti fetusa .

Ključne reči: trudnoća; antitelo, antifosfolipidni; mrtvorođenost.

title or anticardiolipin IgM antibodies small or great increase in two different measurements at least 6 weeks apart) (1). There is an expert opinion, however, that these criteria require reconsideration and that is why an additional approach is attempted in this article (2).

The detection of antiphospholipid antibodies during a pregnancy represents a great challenge for the obstetrician as they could indicate the presence of AS. The timely diagnosis and management of the syndrome results in significant improvement of perinatal outcome mainly due to the prevention of intrapartum thromboses and consequent abortions (3). Many pathogenetic events in 
women with AS might develop during their pregnancies: (i) bonding of antiphospholipid antibodies with phospholipids or phospholipids' proteins such as $\beta 2 \mathrm{GPI}$, prostacyclin, prothrombin, protein $\mathrm{C}$, annexin $\mathrm{V}$, and other tissue factors, that activate hypercoagulation, and/or the (ii) activation of endothelial cells, and/or the (iii) activation of complement $\mathrm{C} 3$ protein (4). These changes have the negative effects on pregnancy causing the placental dysfunction due to thickening of internal layer of spiral arteries along with acute atheromatous and fibrinoid necrosis. However, antiphospholipid antibodies, one of the main diagnostic criteria, are observed in over $5 \%$ of healthy individuals, while the percentage reaches $35 \%$ in cases of individuals with systemic lupus erythematosus (SLE). In addition, there are great differences worldwide in antibody identification tests, particularly in cut-off positive values of IgG antibodies, in performances of IgM or IgA detection and in revealing antibodies against 32 GPI, phosphatidylserine, phosphatidylethanolamine, phosphatidylinositol, phosphatidylglycerol, phosphatidylcholine and phosphatidic acid (5).

\section{THE CASE}

Woman, 36 years old, in the third pregnancy, was admitted in the obstetric department in the spring of 2009, due to absent fetal movements. The course of previous pregnancies, in 2004 and 2005 were normal and the labors were performed at the same health facility. The first male child suffers from one kind of autism spectrum disorders, but the second one is healthy. In this, the third pregnancy, at admission the fetus was 40 weeks of gestational age, but fetal pulses were confirmed absent by ultrasound.Vaginal labor was augmented, a stillborn male neonate had weight of $4000 \mathrm{~g}$, the umbilical cord was normal and it was not wrapped. The course of the gestation was otherwise normal. Diagnostic check-up during the pregnancy was normal such as biochemical investigation of complete blood count, glucose, creatine, uric acid, SGOT, SGPT, urinalysis, hemoglobin electrophoresis, and sickle cell test. Other prenatal laboratory findings were: blood types A, Rhesus (+). Arterial blood pressure 110/80 $\mathrm{mmHg}$, normal male karyotype on amniocentesis, normal ultrasound during $2^{\text {nd }}$ trimester, normal cardiotocogram 3 days before the labor, negative stillborn forensic investigation.

Soon after, during the summer of 2009, extensive diagnostic work-up was performed for the mother in order to find the cause underlying the previous unsuccessful pregnancy. Gynecological, somatic and laboratory investigation was done. The final results of such diagnostic algorithm revealed only the presence of subtle abnormalities in white blood cell lines. This was the reason why in her fourth pregnancy meticulous follow-up was performed resulting in successful pregnancy outcomes.
In detail, during the first set of investigations (between the third and the fourth pregnancies) virological analyses ruled out the presence of cytomegalovirus, herpes simplex virus type 1 and 2, rubella, toxoplasmosis, hepatitis virus A and C, human immunodeficiency virus (HIV-1 and HIV2) and Epstein- Barr virus (EBV) infections. The mother had normal values of the following hormonal and hematological parameters: triiodothyronine (T3), levothyroxine (T4), free-triiodothyronine (fT3), freelevothyroxine (fT4), thyroid-stimulating hormone (TSH), anti-thyroglobulin antibodies (ATA, TgAb, anti-TgAb), anti-thyroid peroxidase antibodies (anti-TPO), fibrinogen, activated partial thromboplastin time (APTT), prothrombin time (PT), D-dimer, lupus anticoagulant, antithrombin III, protein $\mathrm{C}$ and $\mathrm{S}$, (activated protein $\mathrm{C}$ resistance (APCR), plasminogen activity, coagulation factor XII, fibrin degradation products (FDP).

Additionally, immunological analysis were also normal including the following tests: anti-thyroglobulin antibodies (ATA, TgAb, anti-TgAb), anti-thyroid peroxidase antibodies (anti-TPO), lupus anticoagulant, antinuclear antibody (ANA), histone antibody (AHA), cardiolipin antibodies (IgA, IgG, IgM), $\beta 2$ glycoprotein I ( $\beta 2 \mathrm{GPI})$ antibody (IgG, IgM), phosphatidylserine antibody (IgG, IgM) and anti-paternal antibodies. Test of Major histocompatibility complex genes, HLA-B and HLA-DR, were normal (figure 1). Test for genetic polymorphism of prothrombin G20210A, factor V Leiden G1691A, methylenetetrahydrofolate reductase (MTHFR), platelet glycoprotein Ia (GPIa 807C/T) plasminogen activator inhibitor type-1 (PAI-1) polymorphism, were normal.

Finally, white blood cells, monocytes, eosinophils, basophils, both at absolute and at relative proportions, were normal, too. The absolute number and the relative proportion of B lymphocytes (CD19+), NK Cells (CD3-, CD16+, $\mathrm{CD} 56+), \quad \mathrm{CD} 8+\mathrm{T}$ cells, NK-like $\mathrm{T}$ $\mathrm{CD} 3+/ \mathrm{CD} 16+\mathrm{CD} 56+$ cells and $\mathrm{CD} 4+/ \mathrm{CD} 8+$ ratio were normal. However, the relative proportion of $\mathrm{B}$ lymphocytes was increased (range $40 \%$ to $44.8 \%$ ); the relative proportion of $\mathrm{T}$ lymphocytes $(\mathrm{CD} 3+)$ was normal, but their absolute number increased (range 1992/ $\mathrm{mm}^{3}$ to $2081 / \mathrm{mm}^{3}$ ); the absolute number of $\mathrm{T}$ lymphocytes (CD4+) was normal, while their relative proportion increased in a range from $62 \% 70.2 \%$ (figure 2 and 3 ). According to the patient's previous data ( 6 weeks before her admission) this results constitutes a state of persistent lymphocytosis which included the period of the third pregnancy and time after it.

After about two year the woman conceived the fourth time. The unfavorable previous perinatal outcome was the reason for repetition of many of the above-mentioned laboratory investigations. However, the results of these laboratory tests were, in general, normal again. In two 


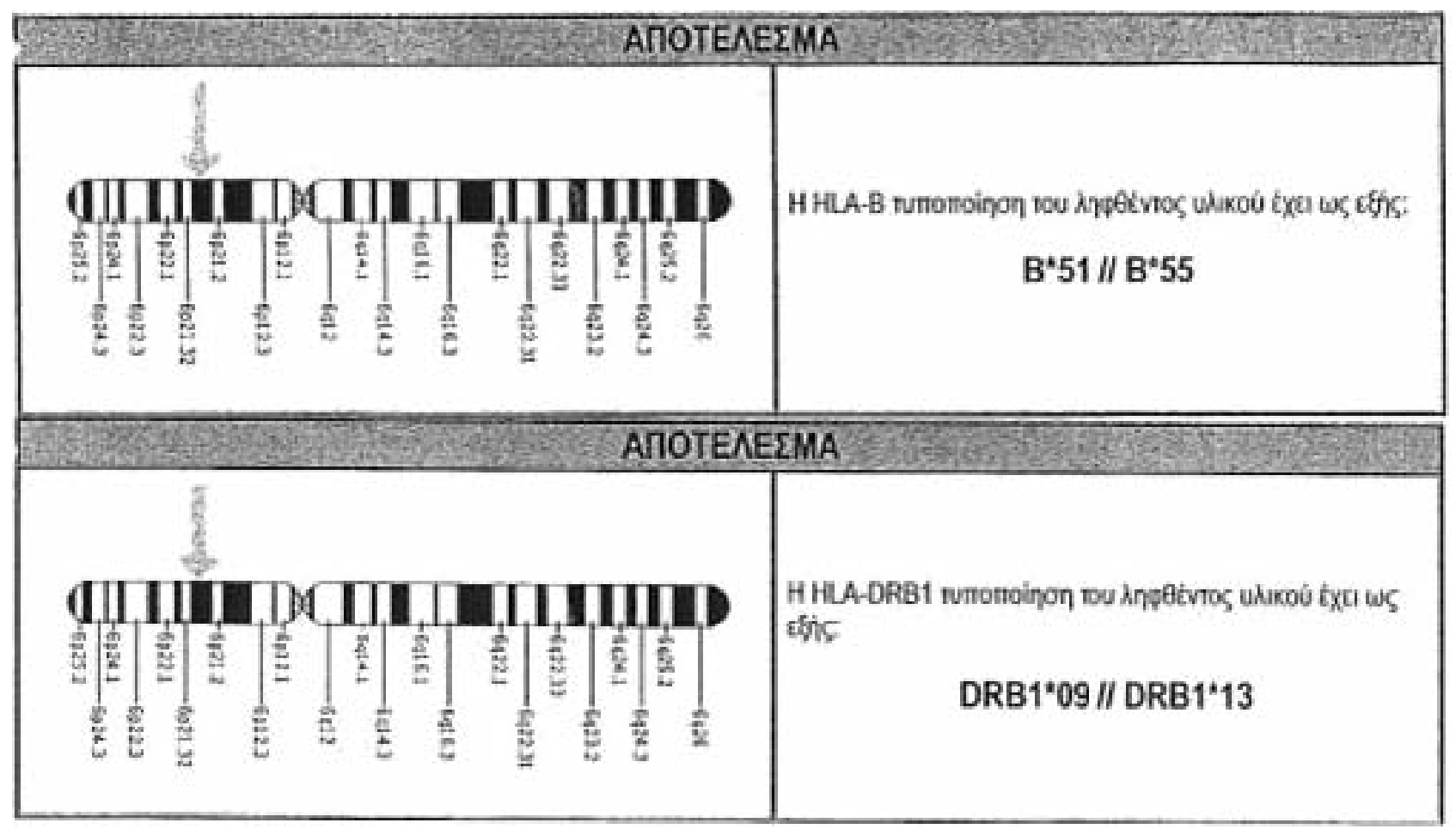

Figure 1. Results of mother's HLA-B and HLA-DR typization (original insert).

\begin{tabular}{|c|c|c|c|}
\hline \multicolumn{4}{|c|}{ 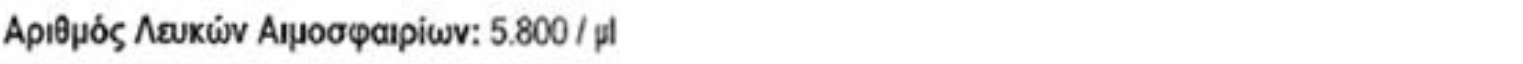 } \\
\hline AEUKOKUTTapiKós Tútros & \% Avahoyia & 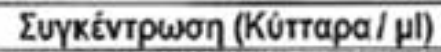 & Tipess Avapopás \\
\hline Dolupopqomupgua & 47. & 2732 & $40.80 \%(2000-7.0001 \%)$ \\
\hline Аєнчоки́ттара & 44.8 & 2.598 & $20-40 \%(1.000-3.000 / \mu l)$ \\
\hline Movorutropa & 64 & 370 & $2.90 \%(200-1.000 / \mu)$ \\
\hline Hwoivópila & 1.2 & 70 & $<1-6 \%(10-500 / \mu l)$ \\
\hline Bátopila & 5005 & 29 & $21 \%(10-1007 \mu)$ \\
\hline
\end{tabular}

Figure 2. Results of mother's hematological analysis, between the third and the fourth pregnancies (original insert).

extremes of blood parameter values, in 10th and 39th weeks of gestational age, relative proportion of lymphocytes was found normal, $30 \%$ and $23.8 \%$, respectively (normal if $<40 \%$ ), which suggests a trend of weekly decline by $0.22 \%$. Similarly, the absolute number of $\mathrm{T}$ lymphocytes was also within reference range, $2100 / \mathrm{mm}^{3}$ and $1809 / \mathrm{mm}^{3}$ respectively (normal if < $3500 / \mathrm{mm}^{3}$ ), which suggested a trend of weekly decline by $10 / \mathrm{mm}^{3}$. Caesarean delivery was scheduled and performed in the 39th week of gestational age, in May 2012 at the public hospital in Agrinio. A healthy male neonate was born, weighting $3520 \mathrm{~g}$.

Therefore, the conclusion for the presented women who had her labors, gynecological, somatic and laboratory investigations and medical treatment in a couple of health facilities could be finally proposed in the following manner. The lymphocytic reaction involving particular cell subpopulations (CD3+, CD4+) during the third pregnancy was associated with unfavorable perinatal outcome. The nature and the pattern of lymphocytic reaction during the period spanning two consecutive pregnancies with different pregnancy outcomes raised the suspicion, with a great probability, that mother during her third pregnancy developed a transient antiphospholipid antibodies with adverse clinical consequences.

\section{DISCUSSION}

Fetal demise during a pregnancy represents important clinical finding in the diagnostic evaluation of existence of immunological abnormalities. In our patient, beside this unfavorable event, there were also several other 


\begin{tabular}{|c|c|c|c|}
\hline \multicolumn{4}{|c|}{ AПOTE $\triangle E \Sigma M A ~ A N O \Sigma O Ф A I N O T Y M I K H \Sigma$ ANA $Y Y \Sigma H \Sigma \Lambda E M \Phi O K Y T T A P \Omega N$} \\
\hline & \% AvaAoyía & 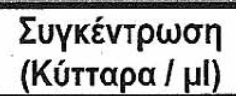 & 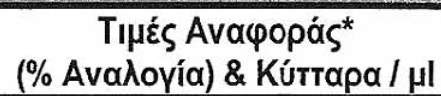 \\
\hline 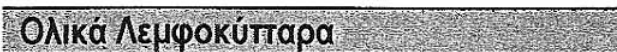 & 44.8 & 2.598 & $(20-40 \%) 1.000-3.000$ \\
\hline 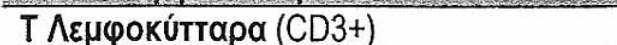 & 80.1 & 2.081 & $(58-87 \%) 582-1.992$ \\
\hline $\mathrm{B} \wedge \varepsilon \mu \varphi$ okutrapa (CD19+) & 9.1 & 236 & $(5-25 \%) 71-567$ \\
\hline NK кútrapa (CD3- CD16+ CD56+) & 10.8 & 281 & $(5-30 \%) 80-597$ \\
\hline \multicolumn{4}{|l|}{ 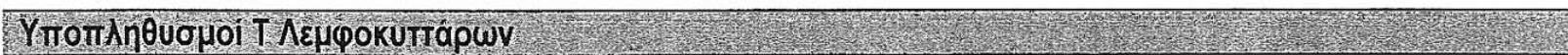 } \\
\hline 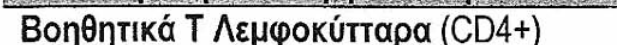 & 70.2 & 1.461 & $(30-62 \%) 401-1.532$ \\
\hline Kataotahtika T A\&ucokurtapa (CD 8+) & 258 & 537 & $(12-42 \%) 152-838$ \\
\hline NK like T кútrapa (CD3+ CD16+ CD56+) & 4.0 & 83 & $15-350$ \\
\hline 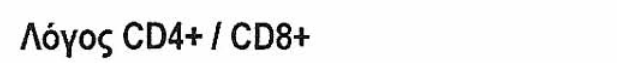 & 2.72 & & $\geq 1.00$ \\
\hline \multicolumn{4}{|l|}{ 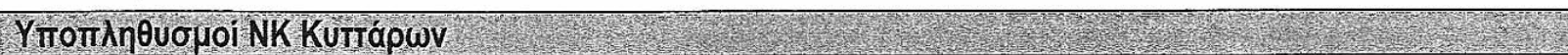 } \\
\hline CD56+, CD16+ & 56.6 & 159 & \\
\hline $\mathrm{CD} 56+, \mathrm{CD} 16$ & 19.6 & 55 & \\
\hline CD56-, CD16+ & 23.8 & 67 & \\
\hline
\end{tabular}

Figure 3. Results of lymphocytic subpopulations of the mother, between the third and the fourth pregnancies (original insert).

pathological findings which concern disturbances of the immune cells, primarily of lymphocytic lines. The pathologically increased relative proportion of lymphocytes, the increased absolute number of $\mathrm{T}$ lymphocytes $(\mathrm{CD} 3+)$ and the increased relative proportion of $\mathrm{T}$ lymphocytes (CD4+) are seen as clinically important diagnostic pattern in the presented woman and other similar cases in our clinical practice. The main question is whether the combination of both findings, fetal demise and lymphocytic disturbances, testify the diagnosis of antiphospholipid antibodies in the absence of wide agreement about the precise role of immune cells at AS suffering women during their pregnancies. The knowledge about the role of immune cells during normal and pathological pregnancies, including the cases of AS and other autoimmune disorders, is accumulating in great extent. Concerning our patient, it is obvious that lymphocytosis decline in combination with good perinatal outcome of the last gestation, enhances the suspicion of probable transient antiphospholipid antibodies during fetal implementation in the previous gestation. In the event of the previous pregnancy, this case simply proves the 3 rd gestation transitory character of antibody.

Several studies connected obstetric or perinatal events with lymphocytes fluctuation, which was the case in our patient. Some reported delayed skin reactions to heparin in pregnant women with antiphospholipid syndrome, with CD3+ and CD4+ lymphocytes in skin biopsy samples (6). Decreased relative proportion and absolute number of circulating CD4+ lymphocytes in patients with primary antiphospholipid syndrome was also reported (7). There were claims that CD4(+), CD25(+)-Treg cells are important for the tolerance function of dendritic cells and macrophages during gestation (8). The Treg lack is accompanied with very early post-implantation losses and spontaneous miscarriages. Other authors reported increased numbers of phenotypically uncommon CD56 shining CD16-maternal natural killer (uNK) cells accompanied with repeated reproductive failure (9). uNK produce angiogenesis growth factors and are potential decidual angiogenic regulators in early gestation through deviating angiogenesis, but also act on non-pregnant endometrium. The mechanisms of reproductive failure accompanied with increased uNK density, appear as the increased angiogenesis and peri-implantation perfusion, that can lead to early development of maternal circulation and thus gestation failure from excessive oxidant stress. Successful implantation is followed by a local preinflammatory Th1 and Th2 correspondence (10). This complicates the sufficient pre-implantation microenvironment which influences the survival of trophoblastic cells and modifies the maternal Treg/T ratio of effector lymphocytes in favor of maternal tolerance. Transfused host leukocytes induced activity of TGF-B suppressor cells, and the surface molecule of CD200 cell that signals the tolerance of mononuclear dendritic cells involved in this discovered effect (11). In fact, the number of CD200 cells granted, were considerably higher in women who achieved gestation and the same was observed in women who achieved a live birth. CD200 mononuclear leukocytes are proved to be an important determinant of subsequent reproductive result for certain 
patients. Women with AS without thrombosis had considerably higher percentages of CD4+ cells than the control ones, higher percentages of activated CD4+, T cells, and lower percentages and absolute amounts of CD4+ cells (12). Those with thrombosis had lower CD3cells, more highly activated CD4+ T cells. On the whole, the long-standing question remains: whether the above mentioned lymphocyte changes is the reason or the result of an ominous gestation outcome.

Other molecules, important for development of AS, also interplay with lymphocytic cells. For example, the importance of $\beta(2)$-glycoprotein I $(\beta(2) \mathrm{GPI})$-specific $\mathrm{CD} 4(+) \mathrm{T}$ cells in the development of pathogenic processes in AS patients is well reported (13). The transforming growth factor-betal (TGF- $\beta 1$ ) of dendritic cells (DC) are feasible to induce antigen-specific unresponsiveness in autoreactive T cells generated in AS patients by inducing apoptosis or $\mathrm{T}$ cells with regulatory abilities. Some researchers did not find significant differences in male-to-female ratio, antiphospholipid IgM isotype, anticardiolipin $\operatorname{IgM}$ and $\operatorname{IgG}$ isotype levels between HIV-infected patients and healthy individuals (14). However, CD4+ T-cell count were significantly lower and antiphospholipid IgG isotype levels were significantly higher in HIV patients. Antiphospholipid IgG isotype and anticardiolipin IgG isotype were significantly higher in HIV-infected women than in HIV-infected men.

In a study, SLE-mice with AS have been characterized by the presence and activity of CD4+ T cells (15). It was shown that $\mathrm{CD} 4+\mathrm{T}$ cell activation through CD28 is critical for disease initiation, but plays small role in disease progression or tissue damage. Others initially identified autoreactive $\mathrm{CD} 4(+) \mathrm{T}$ cells to $\beta(2)$ glycoprotein I $(\beta(2) \mathrm{GPI})$ that promoted AS antibodies aPL production in AS patients $(16,17) . \quad \beta(2) \mathrm{GPI}-$ specific CD4(+) $\mathrm{T}$ cells preferentially recognize the antigenic peptide containing the major phospholipid binding site in the context of DRB4*0103 (DR53). T-cell receptor $\beta$ chains of $\beta(2)$ GPI-specific T cells are highly restricted and mainly utilize rearranged V $\beta 7$ or V $\beta 8$ gene segments. Tcell helper activity that stimulates $B$ cells to produce anti$\beta(2)$ GPI antibodies is mediated through IL-6 and CD40CD40 ligand engagement. $\beta(2)$ GPI-specific $T$ cells respond to reduced $\beta(2) \mathrm{GPI}$ and recombinant $\beta(2) \mathrm{GPI}$ fragments produced in bacteria, but not to native $\beta(2) \mathrm{GPI}$, indicating that the epitope recognized by $\beta(2)$ GPI-specific $\mathrm{T}$ cells are apparently cryptic.

Activation of $\beta(2) \mathrm{GPI}$-specific $\mathrm{T}$ cells resulting in production of pathogenic anti- $\beta(2)$ GPI antibodies can be induced by exposure to cryptic peptides of $\beta(2) \mathrm{GPI}$. $\beta 2$ GPI-specific CD4+ T cells preferentially recognize the antigenic peptide containing the major phospholipid (PL)binding site in the context of DR53 (18). Although $\beta 2 \mathrm{GPI}-$ specific $\mathrm{T}$ cells are detected in both AS patients and healthy individuals, these autoreactive $\mathrm{T}$ cells are activated in vivo in AS patients, but not in healthy individuals. This indicated activation of $\beta 2 \mathrm{GPI}$-specific $\mathrm{T}$ cells and subsequent production of pathogenic anti- $\beta 2 \mathrm{GPI}$ antibodies induced by exposure of such T cells to cryptic peptides of $\beta 2 \mathrm{GPI}$ efficiently presented by functional antigen-presenting cells (APC). There were findings that CD4(+) T cells autoreactive to $\beta(2)$ GPI in AS patients preferentially recognize a cryptic peptide encompassing amino acid residues 276-290 (p276-290), which contains the major PL-binding site, in the context of DR53 (18). The presentation of a disease-relevant cryptic T-cell determinant in $\beta(2)$ GPI is induced as a direct consequence of antigen processing from $\beta(2)$ GPI bound to anionic PL. Dendritic cells or macrophages pulsed with PL-bound $\beta(2)$ GPI induced a response of p276-290-specific CD4(+) T-cell lines generated from patients in an HLA-DRrestricted and antigen-processing-dependent manner, but those with $\beta(2)$ GPI or PL alone did not.

In addition, the p276-290-reactive T-cell response was primed by stimulating peripheral blood $\mathrm{T}$ cells from DR53-carrying healthy individuals with dendritic cells bearing PL-bound $\beta(2) \mathrm{GPI}$ in vitro. Some identified $\mathrm{CD} 4(+) \mathrm{T}$ cells that are autoreactive to $\beta(2)$-glycoprotein I $(\beta(2) \mathrm{GPI})$ and that promote AS antibody production in AS patients (19). V $\beta 7$ and V $\beta 8$ segments were commonly detected in $\beta(2)$ GPI-responders. The analysis of the complementarity-determining region 3 sequence of $\beta(2)$ GPI-reactive $\mathrm{T}$ cells revealed limited diversity, and amino acid motif of TGxxN/Q or minor variations were found in all $\mathrm{V} \beta 7(+)$ TCRs. The V $\beta 8(+)$ TCRs had another motif, PxAxxD/E. Surprisingly, an identical V $\beta 7(+)$ TCR $\beta$ chain was used by $\beta(2)$ GPI-reactive T cells in AS patients. Some of the V $\beta 7(+)$ TCRs with the TGxxN/Q motif were also used by $\beta(2) \mathrm{GPI}$-specific CD4(+) T-cell clones responsive to an immunodominant epitope containing the major phospholipid-binding site. Depletion of $\mathrm{V} \beta 7(+)$ or $\mathrm{V} \beta 8(+) \mathrm{T}$ cells from the peripheral blood mononuclear cell cultures significantly inhibited in vitro anti- $\beta(2) \mathrm{GPI}$ antibody production in response to $\beta(2) \mathrm{GPI}$.

There were at least 4 distinct T-cell epitopes, but the majority of the $\beta 2 \mathrm{GPI}$-specific T-cell clones responded to a peptide encompassing amino acid residues 276 to 290 of $\beta 2 \mathrm{GPI}$ that contains the major phospholipid-binding site in the context of the DRB4*0103 allele (20). Ten of 12 $\beta 2 \mathrm{GPI}$-specific T-cell clones were able to stimulate autologous peripheral blood B cells to promote anti- $\beta 2 \mathrm{GPI}$ antibody production in the presence of recombinant $\beta 2$ GPI. T-cell helper activity was exclusively found in Tcell clones capable of producing interleukin 6 (IL-6). In addition, exogenous IL- 6 augmented anti- $\beta 2$ GPI antibody production in cultures of the T-cell clone. Importantly, $\beta 2$ GPI-specific CD4(+) $\mathrm{T}$ cells in AS patients preferentially recognize the antigenic peptide containing the major phospholipid-binding site. 
Also, seven CD4(+) T cell lines reactive with $\beta(2)$ GPI peptide were found (21). Three of four epitopes for AS/SLE patient-derived $\mathrm{T}$ cell lines were p244-264, whereas one $\mathrm{T}$ cell line from a control subject also recognized p244-264. Furthermore, there was no tendency for particular HLA class II molecules to present $\beta(2)$ GPI peptides. However, cytokine producing patterns were significantly different between $\mathrm{T}$ cell lines from patients and those from healthy individuals; patients' $\mathrm{T}$ cells tend to exhibit higher IL-4 and lower IFN-gamma responses. These $\mathrm{T}$ cell lines did not react to $\beta(2)$ GPI purified from human plasma. They indicated that $\beta(2)$ GPI-reactive CD4(+) $\mathrm{T}$ cells of AS/SLE patients mainly recognize cryptic p244-264 in the context of various HLA class II molecules, and exhibit Th0-Th2-type responses. Earlier, it has been found that AS immunoglobulins are predominantly directed against epitopes on phospholipidbinding plasma proteins, such as $\beta 2$-glycoprotein-1 ( $\beta 2 \mathrm{GP} 1)$ and prothrombin (22). The immune response was Ag-specific, requiring class II molecules, CD4+ T cells, and APCs, and was associated with a selective expansion of CD4+ T cells. The proliferating $\mathrm{T}$ cells produced IFNgamma, indicating a bias toward a type 1 immune response. Chronic low grade stimulation of autoreactive 32 GP1-specific, IFN-gamma-producing Th1 CD4+ T cells may contribute to the high risk of thromboses and pregnancy failure in AS patients.

Concerning $\mathrm{CD} 3(+) \mathrm{T}$ cells as well, there is a published research about CD4 $(+)$ regulatory $\mathrm{T}(\mathrm{Treg})$ cell dysfunction in various autoimmune disorders, but not including AS so far. The percentage of total lymphocytes, activated T helper cells (CD4+), Treg cells and CD3(-) B cells were found significantly lower in AS patients compared to controls (23). A dysfunction in CD4(+) Treg cells and the decreased number of CD3(-) B cells may represent one of the mechanisms leading to autoimmunity in AS patients. In another research, lymphocytic infiltrates of AS mice using antibodies against CD3, CD4 and forkhead box P3 (Foxp3) was characterized immunohistochemically (24). No significant inflammatory reaction occurred and neither GFAP, Iba1, CD68-immunohistochemical activation of astrocytes and/or microglia nor accumulation of macrophages appeared.

In the peripheral blood mononuclear cells (PBMC) fraction from SLE PBMC-infused DKO (SLE-DKO) mice and normal donor PBMC-infused DKO (ND-DKO) mice, an average of $41 \%$ and $53 \%$ human CD $45+$ cells, respectively, were observed at 4 weeks post-engraftment, with 70-90\% CD3+ cells (25). There were fewer $\mathrm{CD} 3+\mathrm{CD} 4+$ cells and more CD3+ cells in the SLE-DKO mice as in the SLE patients from which the PBMCs were derived. In SLE-DKO mice engrafted with (PBMCs) from the aCL-positive patient, microthrombi and infiltration of $\mathrm{CD} 3+$ cells in the glomeruli were found, recapitulating the human AS. The researcher speculated that pathogenesis of thrombosis was related to the development of cellular procoagulant activity through tight occupancy of Fc receptors, or through complement activation, or through cell-cell interactions (26). In the subjects with primary AS there were lower total blood lymphocyte count, an expansion of naive CD4+RA+ cells $(p=0.025)$, a lower proportion of memory $\mathrm{CD} 4+\mathrm{RO}+$ cells and an increased ratio of naive/memory CD4 cells ( $\mathrm{p}=0.015)$, among other (CD3+), CD4+ helper (and CD4+, activated CD4+) T cell subsets group (27).

In conclusion, integrating existing knowledge with outcomes of the consecutive pregnancies, clinical finding, laboratory examinations and disturbances of immune cells in our patient gives possible conclusion that transient antiphospholipid antibodies appeared during the third pregnancy. It is likely that these antibodies triggered the chain of pathological events which finally contributed to the fetal demise. Due to the rarity of similar reports in present literature the case in presented to be one of the evidence for designing future research. They should clarify the role of advanced laboratory methods in diagnostic algorithm of this unusual clinical entity in obstetrics practice.

\section{ABBREVIATIONS:}

AS - antiphospholipid syndrome

$\beta 2$ GPI - $\beta 2$ glycoprotein I

SLE - Systemic lupus erythematosus

\section{REFERENCES}

1. Gardiner C, Hills J, Machin SJ, Cohen H. Diagnosis of antiphospholipid syndrome in routine clinical practice. Lupus 2013; 22: 18-25.

2. Levine JS, Branch DW, Rauch J. The antiphospholipid syndrome. N Engl J Med 2002; 346: 752-63.

3. Lima F, Khamashta MA, Buchanan NM, Kerslake S, Hunt BJ, Hughes GR. A study of sixty pregnancies in patients with the antiphospholipid syndrome. Clin Exp Rheumatol 1996; 14: 131-6.

4. Rand JH, Wu XX, Andree HA, et al. Pregnancy loss in the antiphospholipid-antibody syndrome-a possible thrombogenic mechanism. N Engl J Med 1997; 337: 154-60.

5. Farquharson RG, Quenby S, Greaves M. Antiphospholipid syndrome in pregnancy: a randomized, controlled trial of treatment. Obstet Gynecol 2002; 100: 408-13. 
6. Kim J, Smith KJ, Toner C, Skelton H. Delayed cutaneous reactions to heparin in antiphospholipid syndrome during pregnancy. Int J Dermatol 2004: 43: 252-60.

7. Karakantza M, Theodorou GL, Meimaris N, et al. Type 1 and type 2 cytokine-producing CD4+ and CD8+ T cells in primary antiphospholipid syndrome. Ann Hematol 2004; 83: 704-11.

8. Saito S, Shima T, et al. What is the role of regulatory $\mathrm{T}$ cells in the success of implantation and early pregnancy? J Assist Reprod Genet 2007; 24(9): 37986.

9. Quenby S, Nik H, Innes B, et al. Uterine natural killer cells and angiogenesis in recurrent reproductive failure. Hum Reprod 2009; 24: 45-54.

10. Fraccaroli L, Alfieri J, Larocca L, et al. A potential tolerogenic immune mechanism in a trophoblast cell line through the activation of chemokine induced $\mathrm{T}$ cell death and regulatory $\mathrm{T}$ cell modulation. Hum Reprod 2009; 24: 166-75.

11. Clark DA. Cell-surface CD200 may predict efficacy of paternal mononuclear leukocyte immunotherapy in treatment of human recurrent pregnancy loss. Am J Reprod Immunol 2009; 61: 75-84.

12. Carbone J, Gallego A, Lanio N, et al. Quantitative abnormalities of peripheral blood distinct T, B, and natural killer cell subsets and clinical findings in obstetric antiphospholipid syndrome. J Rheumatol 2009; 36: 1217-25.

13. Torres-Aguilar H, Blank M, Kivity S, et al. Tolerogenic dendritic cells inhibit antiphospholipid syndrome derived effector/memory CD4(+) T cell response to $\beta 2 \mathrm{GPI}$. Ann Rheum Dis 2012; 71: 120-8.

14. Abdollahi A, Morteza A. Serum concentrations of antiphospholipid and anticardiolipin antibodies are higher in HIV-infected women. Rheumatol Int 2012; 32: 1927-32.

15. Akkerman A, Huang W, Wang X, et al. CTLA4Ig prevents initiation but not evolution of antiphospholipid syndrome in NZW/BXSB mice. Autoimmunity 2004; 37: 445-51.

16. Kuwana M. Autoreactive CD4(+) T cells to beta(2)glycoprotein I in patients with antiphospholipid syndrome. Autoimmun Rev 2003; 2: 192-8.

17. Kuwana M. Beta2-glycoprotein I: antiphospholipid syndrome and T-cell reactivity. Thromb Res 2004; 114 : 347-55.
18. Kuwana M, Matsuura E, Kobayashi K, et al. Binding of beta 2-glycoprotein I to anionic phospholipids facilitates processing and presentation of a cryptic epitope that activates pathogenic autoreactive $\mathrm{T}$ cells. Blood 2005; 105: 1552-7.

19. Yoshida K, Arai T, Kaburaki J, et al. Restricted T-cell receptor beta-chain usage by $\mathrm{T}$ cells autoreactive to beta(2)-glycoprotein I in patients with antiphospholipid syndrome. Blood 2002; 99: 2499504.

20. Arai T, Yoshida K, Kaburaki J, et al. Autoreactive CD4(+) T-cell clones to beta2-glycoprotein I in patients with antiphospholipid syndrome: preferential recognition of the major phospholipid-binding site. Blood 2001; 98: 1889-96.

21. Ito H, Matsushita S, Tokano Y, et al. Analysis of T cell responses to the beta 2-glycoprotein I-derived peptide library in patients with anti-beta 2-glycoprotein I antibody-associated autoimmunity. Hum Immunol 2000; 61: 366-77.

22. Visvanathan S, McNeil HP. Cellular immunity to beta 2-glycoprotein-1 in patients with the antiphospholipid syndrome. J Immunol 1999; 162: 6919-25.

23. Dal Ben ER, do Prado CH, Baptista TS, Bauer ME, Staub HL. Decreased Levels of Circulating CD4+CD25+Foxp3+ Regulatory T Cells in Patients with Primary Antiphospholipid Syndrome. J Clin Immunol 2013; 33: 876-9.

24. Frauenknecht K, Katzav A, Grimm C, et al. Neurological impairment in experimental antiphospholipid syndrome is associated with increased ligand binding to hippocampal and cortical serotonergic 5-HT1A receptors. Immunobiology 2013; 218: 517-26.

25. Andrade D, Redecha PB, Vukelic M, et al. Engraftment of peripheral blood mononuclear cells from systemic lupus erythematosus and antiphospholipid syndrome patient donors into BALBRAG-2-/- IL-2R $\gamma$-/- mice: a promising model for studying human disease. Arthritis Rheum 2011; 63: 2764-73.

26. Vermylen J, Van Geet C, Arnout J. Antibody-mediated thrombosis: relation to the antiphospholipid syndrome. Lupus 1998; 7(Suppl 2): S63-6.

27. Papo T, Piette JC, Legac E, et al. T lymphocyte subsets in primary antiphospholipid syndrome. J Rheumatol 1994; $21: 2242-5$

NOTE: Approved on 05.12.2013. 